\title{
Numerical Investigation of the Coastal Atmosphere and Ocean at Meaípe
}

\author{
F. N. D. Ribeiro ${ }^{\mathrm{a}}$, G. Codato ${ }^{\mathrm{b}}$, J. Soares ${ }^{\mathrm{b}}$ \\ ${ }^{a}$ School of Arts, Sciences and Humanities, University of Sao Paulo, Sao Paulo, Brasil. \\ ${ }^{b}$ Institute of Astronomy, Geophysics and Atmospheric Sciences, University of Sao Paulo, Sao Paulo, \\ Brasil.
}

\begin{abstract}
RESUMO
As areias monazíticas de Meaípe atraem grande interesse por sua radiação ionizante. Essa radiação é inerte, mas sua intensidade varia com o tempo e o espaço, podendo sofrer influência das condições atmosféricas. O presente estudo realizou simulações numéricas com o modelo atmosférico Weather Research and Forecasting para investigar a dinâmica atmosférica dessa região costeira. As simulações se referem ao período de 1 a 7 de janeiro de 2019 e incluem a emissão de um traçador com taxa constante para representar a dispersão e o transporte da radiação ionizante pelas circulações atmosféricas. Para o período simulado, observou-se que a direção predominante do vento foi de norte-nordeste. A topografia tem uma influência significativa na circulação atmosférica local e também se observou influência da circulação de brisa marítima. A radiação ionizante não é transportada horizontalmente para uma área muito grande, ficando confinada a uma região próxima de sua emissão. Sua dispersão vertical é normalmente limitada pelo topo da camada limite planetária.
\end{abstract}

\begin{abstract}
The monazite sands of Meaípe attract a great interest because of their ionizing radiation. This radiation is inert, but its intensity varies with time and space, and may be influenced by the atmospheric conditions. The present study performed numerical simulations with the atmospheric model Weather Research and Forecasting to investigate this coastal region atmospheric dynamics. The simulations refer to a period from 01 to 07 January of 2019 and include the emission of an inert tracer with a constant rate to represent the dispersion and transport of the ionizing radiation by the atmospheric circulations. During the simulated period, the predominant wind direction was from north-northeast. Topography has a substantial influence on the local atmospheric circulation and the influence of the sea breeze circulation was also noticed. The ionizing radiation is not horizontally transported to a large area, staying confined to a region near its emission. Its vertical dispersion is usually limited by the top of the planetary boundary layer.
\end{abstract}

\section{Introduction}

Meaípe, a beach at Guarapari city in Espirito Santo state - Brazil, is of great interest because of its monazite sand, that emits an ionizing radiation. Once the radiation is present in the air, it can be transported and dispersed by atmospheric circulations and, therefore, it is necessary to investigate the spatial and temporal evolution of these circulations, particularly the evolution of the planetary boundary layer (PBL).

A meteorological tower was recently installed at Meaípe to record meteorological and soil variables (http://www.iag.usp.br/meteo/liam/data/MEA01/MEA01_RT.html). However, these measurements are taken at a single point. A numerical simulation is able to represent the threedimensional flow at a determined volume of interest and is a valuable tool to help understand the interaction among different scales of atmospheric flow, as well as the interaction between atmosphere and surface.

The Weather Research and Forecasting (WRF) model has being successfully used to simulate atmospheric circulations at coastal areas [1]. It is an open source model, designed for realistic simulations. The model also allows the investigation of the transport and dispersion of inert tracers. Therefore, it is a suitable tool to investigate the influence of the atmospheric circulations on the spatial and temporal variability of the monazite sand ionizing radiation at Meaípe. 


\section{Methodology}

The simulations were performed using the computational numerical atmospheric mesoscale model WRF version 3.8.1. WRF is a three-dimensional Eulerian model, fully compressible, nonhydrostatic, with sigma (terrain-following) coordinates in the vertical direction [2]. At the atmospheric surface layer, the model uses the Monin-Obukhov similarity theory. It also uses the Noah Land Surface Model [3] with 4 soil layers.

A series of combinations of parameterization schemes for different processes is possible. The options used in this work are: the Yonsei University PBL scheme, Grell 3D cumulus scheme, RRTM longwave scheme, and Dudhia shortwave scheme.

The necessary input data are: topography of the area (Fig. 1) obtained from satellite pictures; land/vegetation type or land use (Fig. 2) also obtained from satellite pictures; and initial and boundary meteorological data, obtained from global meteorological model reanalysis ERA-Interim [4], including sea surface temperature every 6 hours.

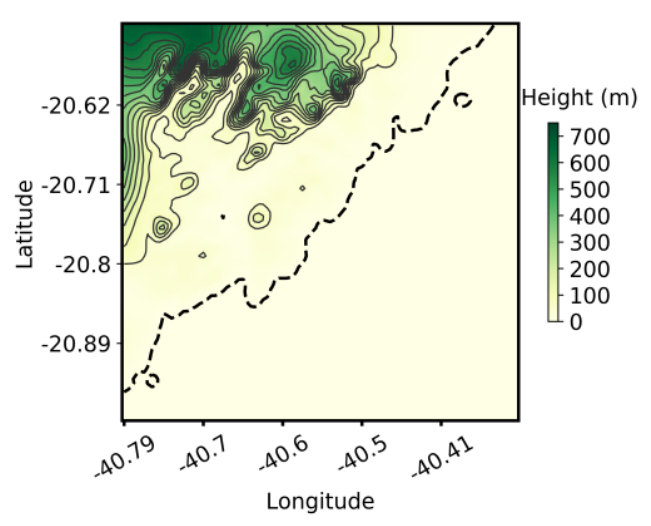

Figure 1: Topography of the innermost domain.

It is also necessary to define the domains: 4 nested domains were used, all with $100 \times 100$ grid points in both horizontal directions, with grid spacing of $62.5 \mathrm{~km}, 12.5 \mathrm{~km}, 2.5 \mathrm{~km}$, and $500 \mathrm{~m}$ from the outermost to the innermost domain. Vertical levels have the smallest grid spacing near the surface and increasing towards the top of the atmosphere. Here 38 levels were used.

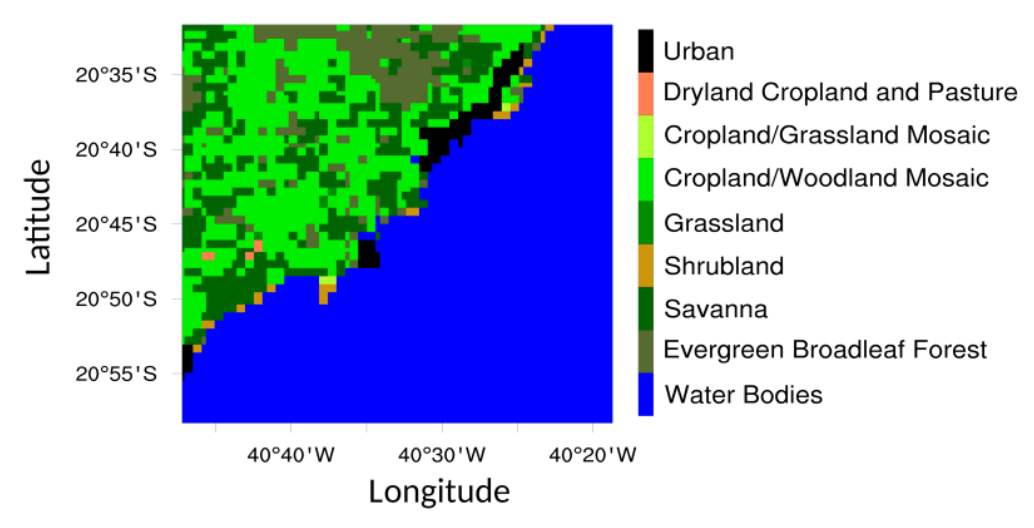

Figure 2: Vegetation type/land use of the innermost domain.

To represent the dispersion and transport of the ionizing radiation, a tracer emission was set up in the WRF model. Some grids at the Meaípe coast emitted a tracer at a constant rate and this tracer was dispersed and transported by the atmospheric circulation.

\section{Results}

Figure 3 shows the time series of near surface variables: air temperature and relative humidity at $2 \mathrm{~m}$ of height and wind speed and direction at $10 \mathrm{~m}$. Temperature (Fig. 3a) and 
humidity (Fig. 3b) show a diurnal pattern compatible with coastal areas: temperature (humidity) increases (decreases) rapidly after sunrise and then decreases (increases) until the other day, probably because of the influence of marine colder and moister air brought by the sea breeze. Wind direction (Fig. 3c) also shows a sea-breeze pattern, with a stronger easterly direction during the late morning and the afternoon. During the simulated period, wind direction was almost always from NNE. Wind speed (Fig. 3d) is relatively high. However, the model tends to overestimate wind speed.

(a)

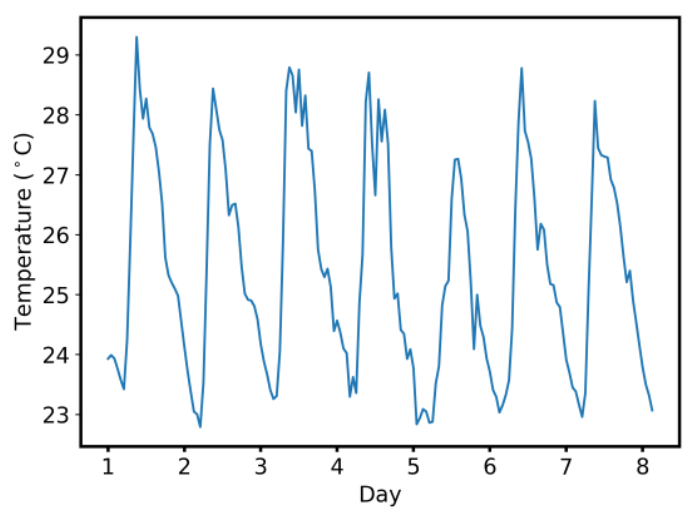

(c)

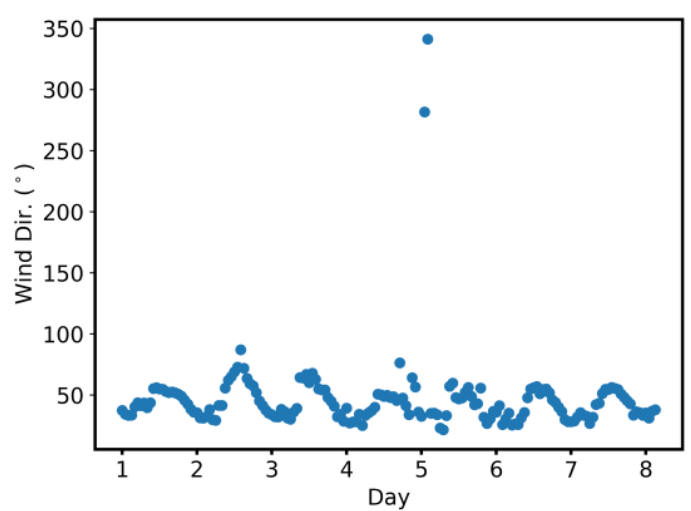

(b)

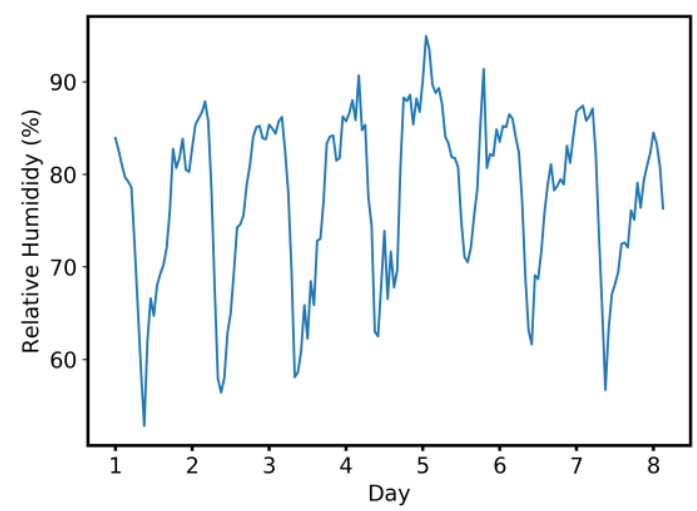

(d)

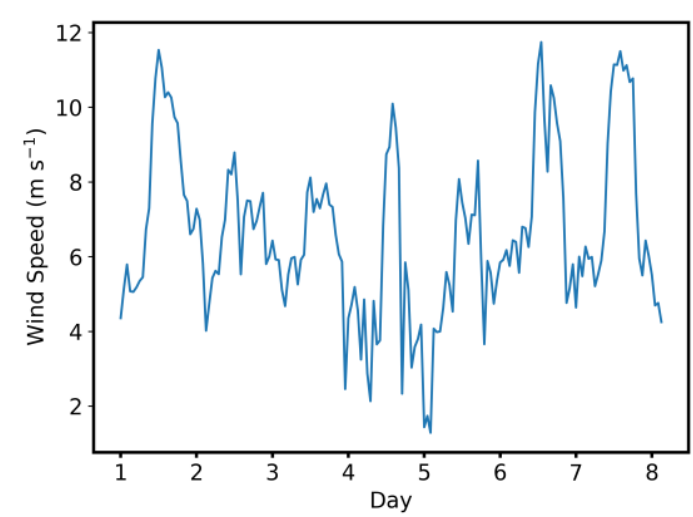

Figure 3: Time series of (a) air temperature at $2 \mathrm{~m}$, (b) relative humidity at $2 \mathrm{~m}$, (c) wind direction at $10 \mathrm{~m}$, and (d) wind speed at $10 \mathrm{~m}$.

The surface variables spatial pattern evolution during the day for the innermost domain is presented in Figure 4. Air temperature increases more rapidly over the continent, creating the thermal gradient that causes sea breeze. In fact, there is a change in wind direction along the coast from 0900 LT (local time, Fig. 4a) to 1200 LT (Fig. 4b) that is the surface flow of the sea breeze circulation. From 1200 LT to 1500 LT (Fig. 4c) and to 1800 LT (Fig. 4d) the inland propagation of marine colder air, caused by the sea breeze, may be noticed along the coast.

Despite the sea breeze influence, wind direction is predominantly from NNE. At 1800 LT, sea breeze is not noticeable anymore. Topography at the northwest corner of the domain also influences the wind flow, creating a convergence over the continent near the coast, where the altitude is smaller. 
(a)

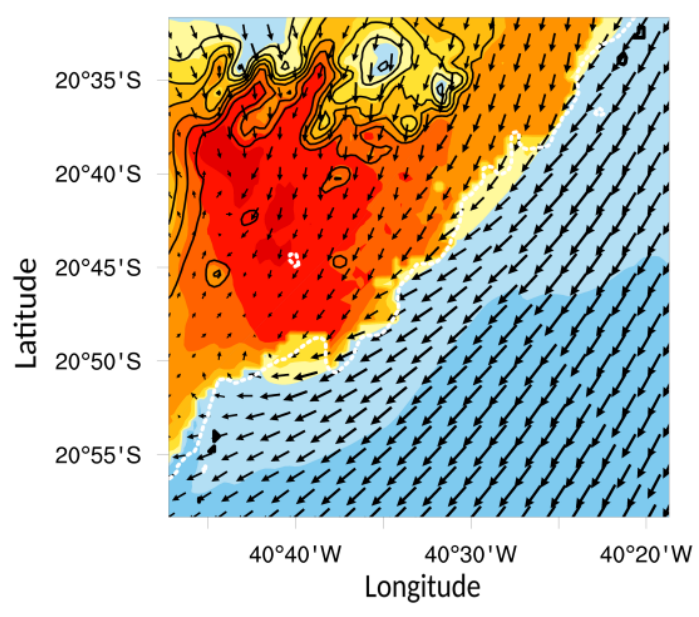

(c)

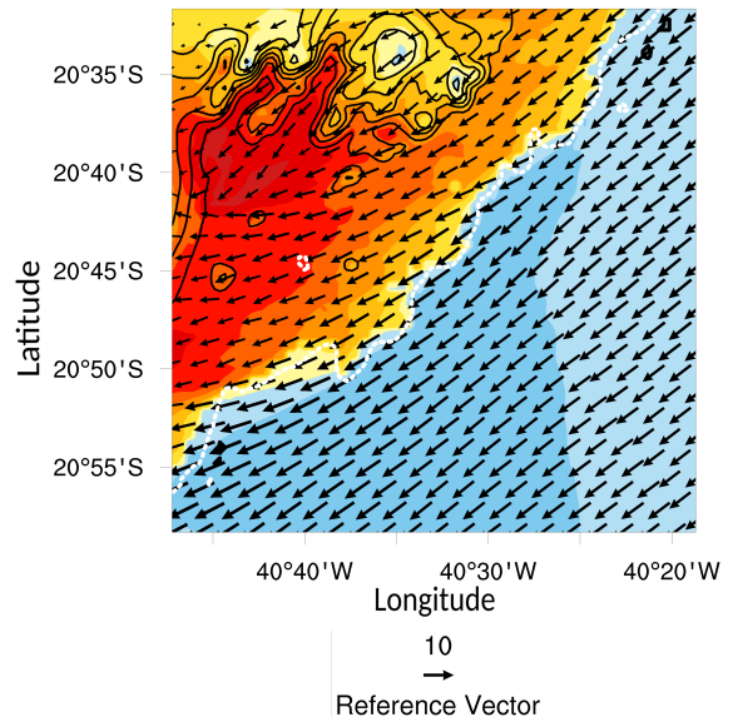

(b)

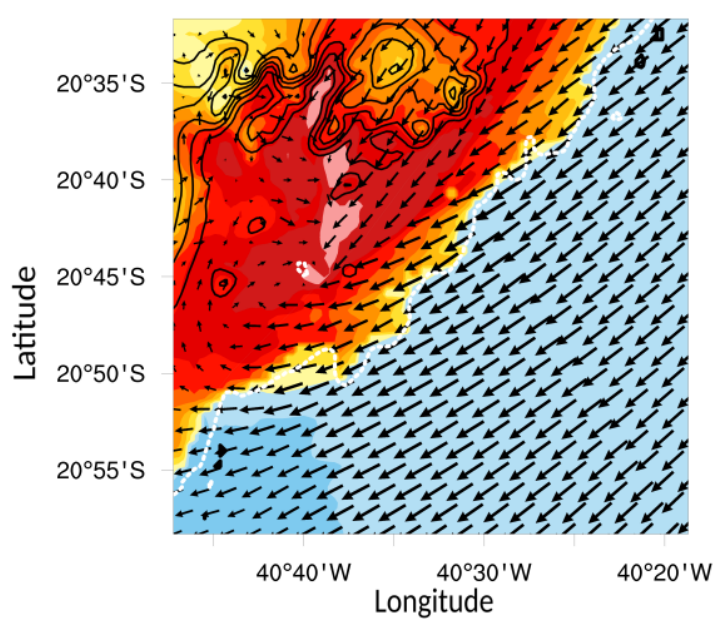

(d)

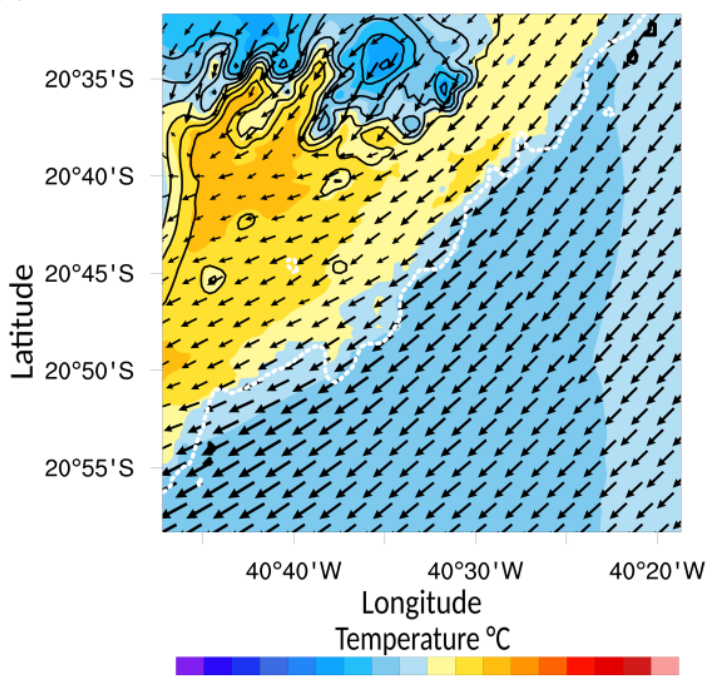

1819202122232425262728293031323334

Figure 4: Near surface air temperature (color scale) and wind velocity (arrows) at the innermost domain at (a) 0900 LT, (b) 1200 LT, (c) 1500 LT, and (d) 1800 LT Jan 01.

At night (Fig. 5), from $2100 \mathrm{LT}$ of the previous day to $0600 \mathrm{LT}$, the temperature slowly decreases and the wind speed over the continent also decreases, except over the northwestern corner of the domain, where the topography greatly influences the wind speed and direction, suggesting the presence of a katabatic flow, that changes from $\mathrm{N}$ at $2100 \mathrm{LT}$ to $\mathrm{NW}$ at $0600 \mathrm{LT}$ of the following day. However, the predominant wind direction is from $\mathrm{NE}$ at the majority of the domain area and a land breeze circulation is not noticeable.

The influence of the predominant wind direction can be noticed at Fig. 6a, that shows the average normalized tracer concentration for the whole simulation period and its transport. The ionizing radiation is kept near its source, only dispersing a low concentration plume to SW areas. In the vertical direction (Fig. 6b), the plume is usually confined in the PBL, that varies from $200 \mathrm{~m}$ to $1.25 \mathrm{~km}$. Since it is a coastal area, the PBL does not reach high values at the coast as it may over the continent. These results indicate that the ionizing radiation is mostly confined to small areas, near its source and near the surface. 
(a)

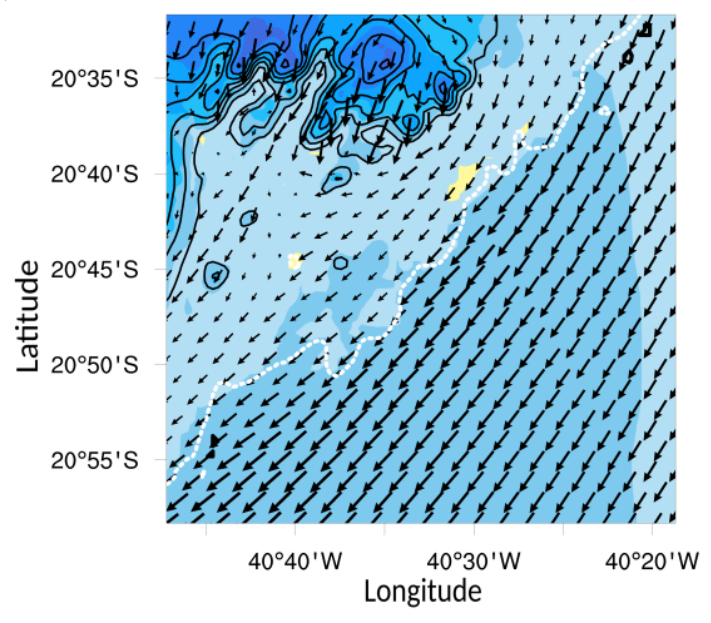

(c)

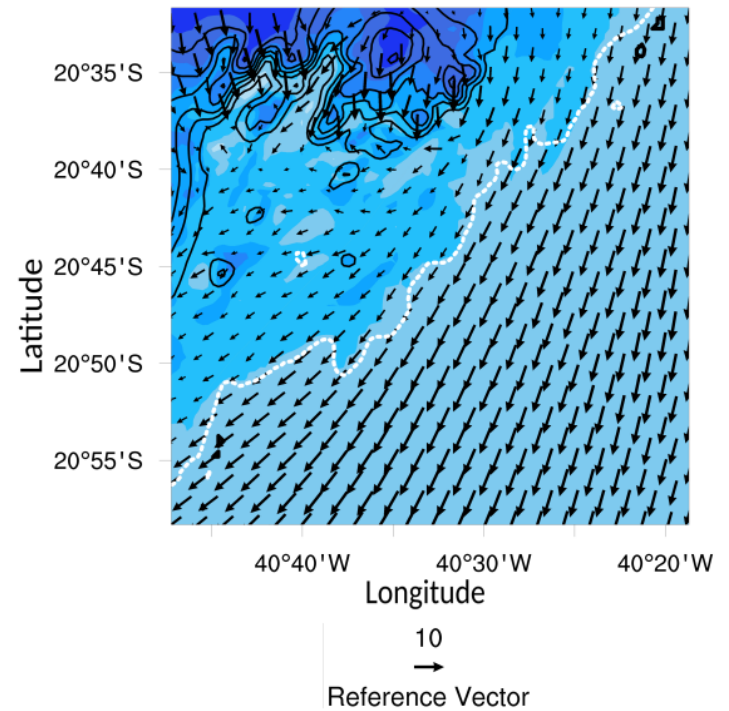

(b)

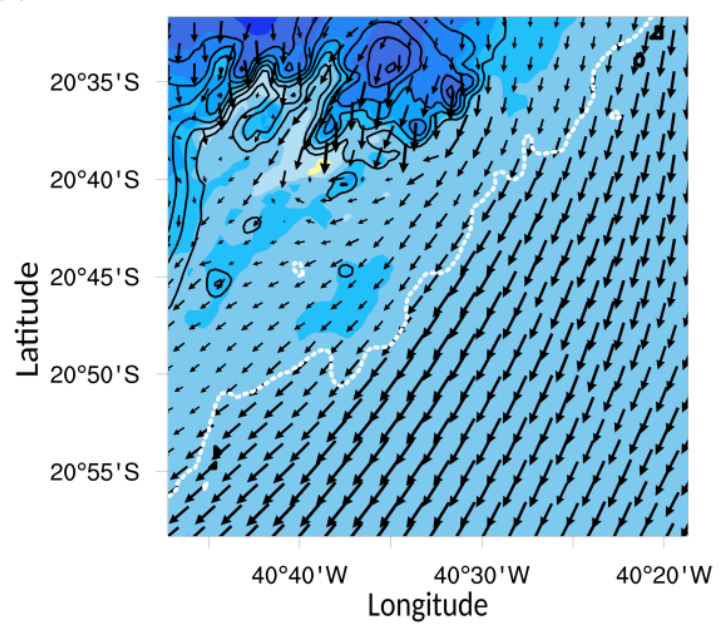

(d)

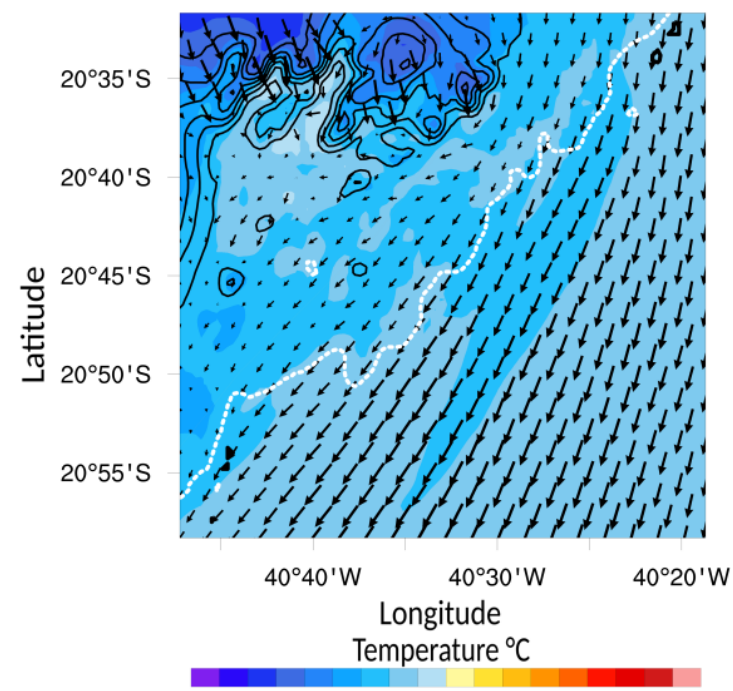

1819202122232425262728293031323334

Figure 5: Near surface air temperature (color scale) and wind velocity (arrows) at the innermost domain at (a) 2100 LT Jan 01, (b) 0000 LT, (c) 0300 LT, and (d) 0600 LT Jan 02.

\section{Discussion}

Meteorological conditions during the period of simulation showed a predominant NE wind flow, with local influence of the sea breeze circulation. Topography also influences local circulation, particularly at night. The ionizing radiation concentration is significantly larger near its source and is usually confined inside the PBL. However, it was transported SW by the predominant wind. PBL height is low near the coast, influenced by sea breeze, preventing radiation vertical dispersion to higher altitudes. In future work, the simulations will be compared to the measurements and may help explain the temporal and spatial variability of the ionizing radiation at Meaípe. 
(a)

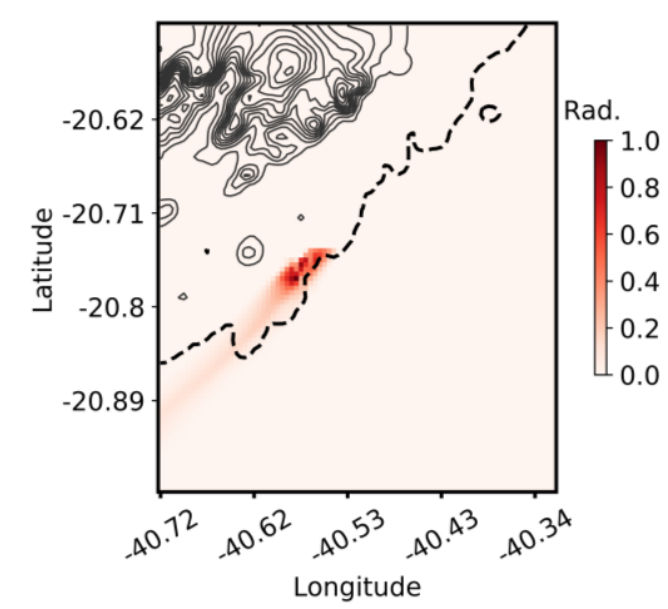

(b)

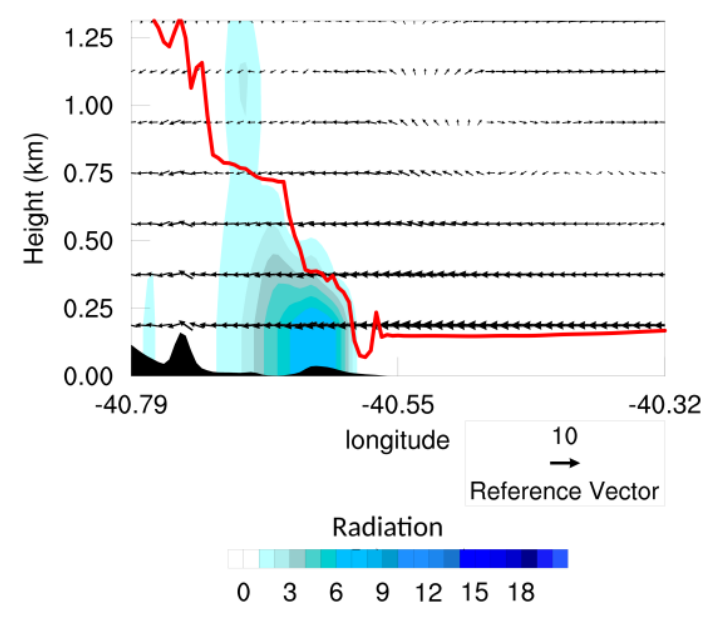

Figure 6: (a) Average normalized (by the maximum) tracer concentration, representing the ionizing radiation, near the surface (inside the surface layer). (b) Tracer concentration in a longitude/altitude cross section along latitude 20 44'6' 'S. Red line is the PBL height. Vectors are the zonal and vertical components of the wind at 1200 LT in 02 Jan 2019.

\section{References}

[1] Ribeiro, F. N., de Oliveira, A. P., Soares, J., de Miranda, R. M., Barlage, M., \& Chen, F. Effect of sea breeze propagation on the urban boundary layer of the metropolitan region of Sao Paulo, Brazil. Atmospheric research, 214, 174-188 (2018).

[2] Skamarock, W.C., Coauthors. A description of the Advanced Research WRF version 3. NCAR Tech., p. 113, DOI: 10.5065/D68S4 MVH Note NCAR/TN-475+STR (2008).

[3] Ek, M. B., Mitchell, K. E., Lin, Y., Rogers, E., Grunmann, P., Koren, V., ... \& Tarpley, J. D. Implementation of Noah land surface model advances in the National Centers for Environmental Prediction operational mesoscale Eta model. Journal of Geophysical Research: Atmospheres, 108 (D22) (2003).

[4] Dee, D.P., Coauthors. The ERA-interim reanalysis: configuration and performance of the data assimilation system. Q. J. R. Meteorol. Soc., 137 (656), pp. 553-597, DOI: 10.1002/qj.828, (2011).

Acknowlegments: The authors would like to thank the support of the funding agencies FAPESP, FAPES, and CNPq. 